\title{
R.O. Dillman
}

\section{Radioimmunotherapy of B-cell lymphoma with radiolabelled anti-CD20 monoclonal antibodies}

\author{
Received: 17 December 2005 / Accepted: 17 December 2005
}

\begin{abstract}
CD20 has proven to be an excellent target for the treatment of B-cell lymphoma, first for the chimeric monoclonal antibody rituximab (Rituxan ${ }^{\mathrm{TM}}$ ), and more recently for the radiolabelled antibodies Y-90 ibritumomab tiuxetan (Zevalin ${ }^{\mathrm{TM}}$ ) and I-131 tositumomab (Bexxar ${ }^{\mathrm{TM}}$ ). Radiation therapy effects are due to beta emissions with path lengths of 1-5 mm; gamma radiation emitted by I-131 is the only radiation safety issue for either product. Doselimiting toxicity for both radiolabelled antibodies is reversible bone marrow suppression. They produce response rates of $70 \%-90 \%$ in low-grade and follicular lymphoma and $40 \%-50 \%$ in transformed low-grade or intermediate-grade lymphomas. Both products produce higher response rates than related unlabelled antibodies, and both are highly active in patients who are relatively
\end{abstract}

R.O. Dillman ( $(\mathbb{})$

Medical and Scientific Director,

Hoag Cancer Center,

Newport Beach, CA 92658, USA

e-mail: rdillman@hoaghospital.org

Tel.: +1-949-760-2091

Fax: +1-949-760-2102 resistant to rituximab-based therapy. Median duration of response to a single course of treatment is about 1 year with complete remission rates that last 2 years or longer in about $25 \%$ of patients. Clinical trials suggest that antiCD20 radioimmunotherapy is superior to total body irradiation in patients undergoing stem cell supported therapy for B-cell lymphoma, and that it is a safe and efficacious modality when used as consolidation therapy following chemotherapy. Among cytotoxic treatment options, current evidence suggests that one course of anti-CD20 radioimmunotherapy is as efficacious as six to eight cycles of combination chemotherapy. A major question that persists is how effective these agents are in the setting of rituximab-refractory lymphoma. These products have been underutilised because of the complexity of treatment coordination and concerns regarding reimbursement.

Key words CD20 • B-cell lymphoma • Y-90 ibritumomab tiuxetan $\cdot$ I-131 tositumomab

$\mathrm{CD} 20$ has proven to be an excellent target for the treatment of B-cell lymphoma [1]. More than $90 \%$ of B-cell lymphoma cells express CD20, but it is not expressed on cells in stem cell and progenitor pools. Rituximab (Rituxan ${ }^{\mathrm{TM}}$, Genentech Inc., South San Francisco, CA, and BiogenIDEC Pharmaceutical Corp, San Diego, CA), a mousehuman chimeric monoclonal antibody that reacts with CD20, has proven to be highly effective and relatively non-toxic in the treatment of B-cell malignancies [2, 3]. As a single agent in indolent B-cell lymphoma, rituximab produces response rates ranging from $50 \%$ to $80 \%$, with median response durations of a year or more [4-8]. In combination with chemotherapy it has produced response rates of more than 90\% [9-11]. Randomised trials have confirmed the superiority of giving rituximab concurrently with chemotherapy in the treatment of large B-cell lym- 
phoma and low-grade lymphoma [12-16]. Since the introduction of rituximab, survival rates for lymphoma patients in the general population have improved significantly for the first time in 30 years [17-19]. However, it is becoming evident that even rituximab is seldom if ever curative whether used alone or in combination with chemotherapy, in low-grade lymphomas. Thus, there is a continuing need for additional agents in the treatment of low-grade lymphomas, whose natural history typically involves a series of responses to treatment and relapses over a median of 10-15 years, and sometimes for more than 20 years, as well as in the treatment of more aggressive lymphomas.

During the past 5 years, two additional anti-CD monoclonal antibody products have been approved in the United States for the treatment of B-cell lymphomas: the radiolabelled antibodies Y-90 ibritumomab tiuxetan (Zevalin ${ }^{\mathrm{TM}}$, Biogen-IDEC Pharmaceuticals, San Diego, CA) and I-131 tositumomab (Bexxar ${ }^{\mathrm{TM}}$, GlaxoSmithKline, Research Triangle Park, NC) [20, 21]. Zevalin was approved for clinical use in February 2002, and Bexxar in June 2003. The descriptive features of these products are summarised in Table 1. Rather than modifying the original mouse antibodies ibritumomab and tositumomab to chimeric or humanised constructs, both were kept as murine proteins in order to decrease half-life in the circulation, to reduce nonspecific total body irradiation (TBI). Ibritumomab is the same antibody that was modified to create the chimeric antibody rituximab; therefore, it has exactly the same binding to CD20 as rituximab. In addition to possible immunologic or regulatory effects mediated via CD20, both products also produce cytotoxic effects from beta radiation associated with the decay of their respective isotopes. Because the path length for the beta radiation extends only for a few millimetres, there are virtually no radiation safety issues for that aspect of the therapy. However, the gamma radiation from $\mathrm{I}-131$ does travel through tissues for several feet. In the past, nuclear medicine specialists had become facile in the use of I-131 for the treatment of hyperthyroidism and thyroid cancer, but such treatments historically had been carried out on inpatient units with isolation precautions. In 1998, changes in regulatory standards by the United States Nuclear Regulatory Commission made outpatient treatment with I-131 and I-131-labelled antibodies feasible $[22,23]$. However, there are still certain radiation safety and relative isolation procedures that are in place during the administration of the I-131-labelled product, including relative isolation from family members for two to four days, for patients receiving this isotope [24].

The rationale for radioimmunotherapy using monoclonal antibodies conjugated to radioisotopes is several-fold. First, lymphoma cells are typically radiosensitive; so, focal external beam, total nodal irradiation and TBI have been used in various treatment strategies for decades. However, focal external beam radiation requires anatomic localisation of a target via scans, and TBI dosing is limited by toxicity to normal tissue. Radioimmunotherapy is a systemic therapy that does not require visualisation of the tumour, and is specific in its targeting of tumour cells; so higher radiation doses can be delivered to tumour cells than is possible in TBI approaches with external beam equipment. Because of radiation path lengths of a few millimetres, radiolabelled antibodies do not have to bind to every single tumour cell for a therapeutic effect. This has been called "the cross-fire effect". In contrast, unlabelled antibodies that target tumour surface antigens have no basis for a therapeutic effect in the absence of binding to the tumour cell. Finally, in radioimmunotherapy the radiolabelled antibodies provide an added dimension, cytotoxic irradiation, to immunologic and regulatory effects associated with antibody binding to antigen/receptor surface molecules.

The schedule for administration of these products is similar, as illustrated in Fig. 1. Both treatment schemes

Table 1 Characteristics of anti-CD20 radiolabelled monoclonal antibodies for radioimmunotherapy of CD20-positive B-cell lymphomas

\begin{tabular}{|c|c|c|}
\hline Product & Y-90 ibritumomab tiuxetan & I-131 tositumomab \\
\hline Radiolabelled MoAb & Mouse anti-CD20 & Mouse anti-CD20 \\
\hline Isotope conjugation & $\begin{array}{l}\text { Indirect: Y-90 chelated to tiuxetan } \\
\text { which is covalently linked to } \\
\text { antibody via arginine \& lysine } \\
\text { amino acids }\end{array}$ & $\begin{array}{l}\text { Direct: I- } 131 \text { iodination of tyrosine } \\
\text { amino acids in the antibody }\end{array}$ \\
\hline Therapeutic isotope & Yttrium-90 & Iodine-131 \\
\hline Half-life & 2.6 days & 8 days \\
\hline Emission path length and energy & $5 \mathrm{~mm} \beta, 2.29 \mathrm{mEv}$ & $1 \mathrm{~mm} \beta, 0.616 \mathrm{mEv}$ and $\gamma, 0.36 \mathrm{mEv}$ \\
\hline $\begin{array}{l}\text { Unlabelled MoAb given prior } \\
\text { to radiolabelled MoAb }\end{array}$ & Chimeric rituximab $250 \mathrm{mg} / \mathrm{m}^{2}$ & Mouse tositumomab $450 \mathrm{mg}$ \\
\hline Tracer imaging dose & $\begin{array}{l}5 \mathrm{mCi} \text { In-111 ibritumomab tiuxetan } \\
\text { day } 1\end{array}$ & 5 mCi I-131 tositumomab day 1 \\
\hline Purpose of tracer/imaging dose & $\begin{array}{l}\text { Imaging of biodistribution as } \\
\text { additional safety measure }\end{array}$ & $\begin{array}{l}\text { Determine retention and urinary clearance } \\
\text { to calculate therapeutic dose }\end{array}$ \\
\hline
\end{tabular}




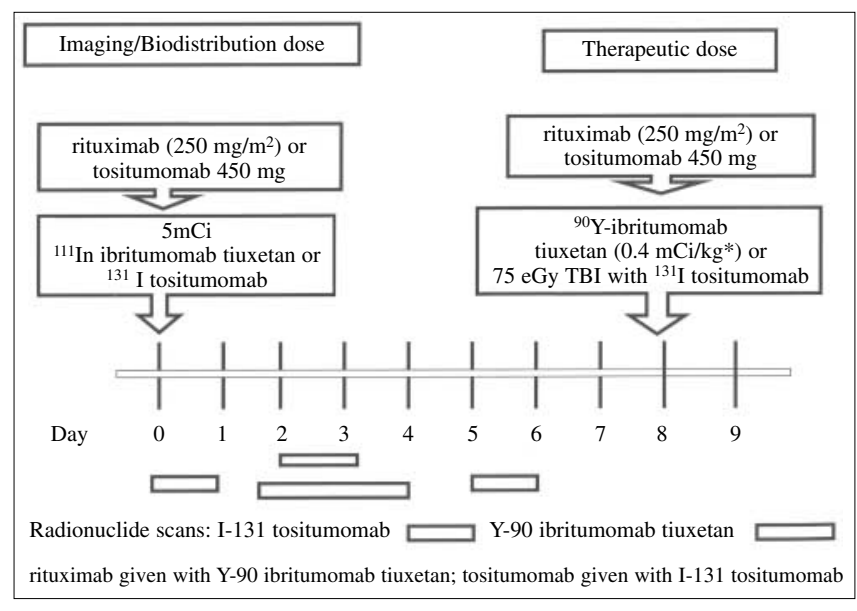

Fig. 1 Schema for anti-CD20 radiolabelled monoclonal antibody radioimmunotherapy for $\mathrm{CD} 20$ positive B-cell lymphoma

include administration of about $500 \mathrm{mg}$ of unlabelled antibody to clear CD20-expressing B cells from the circulation and to bind B lymphocytes that reside in the spleen. This results in a better biodistribution of the relatively small amount (about $35 \mathrm{mg}$ ) of radiolabelled antibody, and therefore a better opportunity to bind to CD20 on tumour cells. At the present time both schedules include an imaging dose prior to the treatment dose. In the case of the yttrium product, this has been required by the US Food and Drug Administration (FDA) to ensure a relatively normal biodistribution that includes elimination from the blood pool, uptake in liver and spleen, but little or no uptake in the kidneys. For this purpose, indium-111 rather than yttrium-90 is conjugated to the antibody, via the same chelating linker, because the latter does not have emissions that are useful for imaging. At the time of approval the FDA required two to three scans for the Zevalin treatment [25], but recently this has been reduced to one, and in Europe the product has been approved without the requirement for such scans as they do not predict efficacy or toxicity at the standard dose of $4 \mathrm{mCi} / \mathrm{kg}$ up to a maximum dose of $32 \mathrm{mCi}$ [26-28]. An analysis based on the pretreatment weight of patients found no difference in response rates for those with weights above $80 \mathrm{~kg}$ compared to those with weights below $80 \mathrm{mg}$ [29]. The tiuxetan chelator is tightly bound to the antibody, and retains the yttrium; therefore, clearance of unbound yttrium is not a significant issue in dosimetric variation. In contrast, in the case of the iodinated product, the scanning is an essential part of determining the retention and clearance of the isotope in order to calculate an optimal therapeutic dose, inasmuch as $50 \%-90 \%$ of the iodine is cleared in the urine during the first $48 \mathrm{~h}$ after administration, and varies tremendously from patient to patient. This necessitates determination of residence time and clearance of the isotope in each individual patient to avoid underdosing or overdosing the therapeutic dose for an individual patient. Because of the potential for uptake of radioactive iodine in the thyroid, free iodine is administered before, during and after therapy for a total of 4 weeks.

Table 2 summarises the phase I trials that were conducted with these products. These studies defined maximum tolerated doses as $75 \mathrm{cGy}$ of TBI for the I-131 product [30] and $4 \mathrm{mCi} / \mathrm{kg}$ for the Y-90 product [31]. The only significant toxicities observed were mild infusion-associated reactions related to the binding of the unlabelled antibodies to circulating tumour cells [32], and reversible cytopenias due to irradiation of haematopoietic precursor cells. The nadir of the cytopenias typically occurred in the second month after treatment, and usually returned to normal levels during the third month. The tumour response rates of around $70 \%$ were much higher than typically reported for phase I trials. About $75 \%$ of the patients had indolent or low-grade lymphomas, in which the response rate was about $80 \%$, and the other $25 \%$ had more aggressive histologies in which the response rate was closer to $40 \%$.

Table 3 summarises the activity of the anti-CD20 radiolabelled antibodies in patients with low-grade lymphoma that had relapsed after prior therapy, typically chemotherapy rather than rituximab, or combinations of chemotherapy

Table 2 Phase I clinical trials with anti-CD20 radiolabelled monoclonal antibodies for relapsed and transformed indolent B-cell lymphoma $[30,31]$

\section{I-131 tositumomab}

59

50

71

Patient population: percent low-grade or transformed

Dose range

Maximum tolerated dose

Dose limiting toxicity

Response rate, \%

Median duration response, months

Complete response rate, $\%$
Y-90 ibritumomab tiuxetan

57

60

67

$0.2-0.4 \mathrm{mCi} / \mathrm{kg}$

$0.4 \mathrm{mCi} / \mathrm{kg}$

Haematologic pancytopenia

67

12 
and rituximab. Response rates were about $80 \%$ in patients with follicular lymphoma [33-35], 70\% in patients considered "resistant" to chemotherapy $[35,36]$ and $40 \%$ in transformed lymphomas [37, 38]. For purposes of these trials, chemotherapy resistance was defined as either no response to the regimen, or a response that lasted less than 6 months. Expanded access trials conducted with these products have yielded similar results in larger populations of patients [39].

Table 4 summarises randomised trials that compared the radiolabelled anti-CD20 antibodies to unlabelled tositumomab or rituximab in patients with low-grade lymphomas, mostly follicular, who had not previously been treated with a monoclonal antibody. The response rates and complete response rates were much higher for the radiolabelled antibodies [35, 40]. The response rates observed for rituximab in the Zevalin $v$ s. rituximab trial were similar to those reported in the pivotal trial of rituximab as a single agent in patients with recurrent low-grade lymphomas [4]. Based on trials of planned "maintenance" rituximab in low-grade lymphoma [7,8], it is likely that the duration of response in the radioimmunotherapy arm would have been much longer if an equivalent amount of rituximab had been given in that arm as in the control arm. In the I-131 tositumomab trial, the response rate was $68 \%$ among 19 patients who subsequently received the radiolabelled antibody after initial randomisation and therapy with unlabelled tositumomab; only three of these patients had responded to tositumomab [40].

Table 5 summarises trials with the anti-CD20 antibodies that were conducted in patients with CD20-positive follicular lymphoma who had tumours that were considered "refractory" to rituximab [41, 42]. For purposes of these trials, "refractory" was defined as lack of an objective tumour regression in response to rituximab, or disease progression despite rituximab therapy (true refractoriness), or an objective response that lasted less than 6 months. In the I-131 tositumomab trial [42], five patients were enrolled who had experienced a response of greater

Table 3 Clinical activity of radiolabelled anti-CD20 monoclonal antibodies in relapsed low-grade lymphomas [33-38]

\begin{tabular}{|c|c|c|}
\hline & I-131 tositumomab & Y-90 ibritumomab tiuxetan \\
\hline \multicolumn{3}{|l|}{ Follicular } \\
\hline Number of patients & 185 & 73 \\
\hline Response rate, $\%$ & 81 & 80 \\
\hline Median duration response, months & 11 & 14 \\
\hline Complete response rate, $\%$ & 38 & 30 \\
\hline \multicolumn{3}{|l|}{ Transformed } \\
\hline Number of patients & 71 & 15 \\
\hline Response rate, $\%$ & 39 & 53 \\
\hline Complete response rate, $\%$ & 25 & - \\
\hline \multicolumn{3}{|l|}{ Chemo-resistant } \\
\hline Number of patients & 60 & 33 \\
\hline Response rate, $\%$ & 65 & 73 \\
\hline Median duration response, months & 6.5 & - \\
\hline Complete response rate, $\%$ & 20 & - \\
\hline
\end{tabular}

Table 4 Randomised trials of radiolabelled anti-CD20 monoclonal antibodies compared to unlabelled antibody in patients with recurrent low-grade lymphoma including small lymphocytic, follicular and transformed low-grade lymphoma, who had not received monoclonal antibody treatment in the past $[35,40]$

\begin{tabular}{lll}
\hline & I-131 tositumomab & Y-90 ibritumomab tiuxetan \\
\hline Number of patients & 78 & 143 \\
Median age of patients, years & 56 & 58 \\
Median number prior therapies & 2 & 2 \\
Percent chemo-resistant & 23 & 48 \\
Control therapy & 450 mg tositumomab $\times 2$ & $250 \mathrm{mg} / \mathrm{m}^{2}$ rituximab $\times 2$ \\
Dose limiting toxicity & Haematologic pancytopenia & Haematologic pancytopenia \\
Response rate & $55 \%$ vs. $19 \% P=0.002$ & $80 \%$ vs. $56 \% P=0.002$ \\
Median duration response & NR vs. 28 months nsd & 15.4 vs. 13.8 months nsd \\
Complete response rate & $33 \%$ vs. $8 \% P=0.012$ & $30 \%$ vs. $16 \% P=0.04$
\end{tabular}

$N R$, not reached; $n s d$, not statistically significant 
Table 5 Phase II trials of radiolabelled anti-CD20 monoclonal antibodies in patients with follicular lymphoma that was considered "refractory" to rituximab (no objective response or response of less than 6 months duration following rituximab) [41] or had progressed after rituximab therapy [42]

\begin{tabular}{lll}
\hline & I-131 tositumomab & Y-90 ibritumomab tiuxetan \\
\hline Number of patients & 40 & 54 \\
Median age of patients, years & 57 & 54 \\
Median number prior therapies & 4 & 4 \\
$\geq$ High-intermediate IPI score, $\%$ & 21 & 19 \\
Rituximab "refractory", $\%$ & 88 & 100 \\
Percent with a tumour $\geq 5 \mathrm{~cm}, \%$ & 50 & 74 \\
Percent with a tumour $\geq 7 \mathrm{~cm}, \%$ & 32 & 44 \\
Bone marrow involved, $\%$ & 32 & 32 \\
Response rate, $\%$ & 65 & 74 \\
Median progression-free survival, months & 10.4 & 6.8 \\
Complete response rate, $\%$ & 38 & 16 \\
\hline
\end{tabular}

$I P I$, international prognostic index; $L D H$, lactate dehydrogenase

than 6 months, but the analysis was performed on all 40 patients as a group of patients who had progressed after rituximab, 24 of whom actually progressed during rituximab therapy, 11 who had a response to rituximab that lasted less than 6 months, and the five who had responded to rituximab for more than 6 months. Because of the differences in patient populations one must be careful in trying to draw conclusions regarding the comparable activity of the two products in this setting. For instance, higher proportions of patients in the Y-90 ibritumomab tiuxetan trial had rituximab-refractory disease, and/or bulky disease greater than $7 \mathrm{~cm}$ in diameter [41]. Response rates were high in both trials, but the complete response rates were lower and duration of response shorter in the Zevalin patients than in other trials of this product, while the complete response rate and duration of response with Bexxar were similar to what had been seen in other trials. This raises the issue of whether rituximab resistance or refractoriness might be associated with changes in the CD20 structure that results in decreased affinity or avidity for the radiolabelled ibritumomab, which binds exactly like rituximab. Tositumomab binds to CD20 via different epitopes; so it is possible that in the setting of rituximab resistance, it might have more favourable binding characteristics than ibritumomab which could be associated with better retention of the isotope at the tumour site.

Recent treatment with rituximab prior to radioimmunotherapy with anti-CD20 radiolabelled antibodies may alter the prevalence of available CD20 binding sites. Under these circumstances, the 400-500 mg of unlabelled antibody tositumomab or rituximab may be more than is needed for optimal pharmacokinetics and biodistribution of the radiolabelled antibodies, and may occupy most or all of the CD20 sites so that there is limited opportunity for the radiolabelled antibody to bind. In such situations most of the radioimmunotherapy effect might result from nonspecific TBI rather than tumour-specific binding. In the "rituximab-refractory" trial with Zevalin, patients who had detectable levels of rituximab in their serum had a response rate of $66 \%$, while those who did not have measurable residual rituximab had a response rate of $93 \%$ $(P=0.078)$ [41]. The presence of CD20-positive cells may be a better indicator of the appropriateness of standard dosing with Zevalin. In the "rituximab-refractory" trial, patients who had detectable CD20-positive cells in the circulation had a response rate of $88 \%$ compared to only $47 \%$ for patients who did not have CD20-positive B cells present $(P=0.003)$ [41]. This issue was not addressed in the I131 tositumomab trial of patients who had progressed after previous rituximab therapy [42].

For all patients that were enrolled in the various registration trials that led to approval of these products (250 for Bexxar, 211 for Zevalin), about $33 \%$ had a durable response of greater than a year, and about $25 \%$ had complete responses that lasted more than a year [43-45]. The median time to progression for all responders was 2.4 years in the Zevalin trials and 3.8 years in the Bexxar trials. The median time to progression for the durable complete responders was 2.6 years in the Zevalin, and not reached at a median follow-up of 5.3 years in the Bexxar trials. Once again it is possible that the apparent difference in duration of response is due to prognostic differences in the patient populations, or it is possible that the durability of response in the Zevalin trials is being reduced because of key differences in the CD20 molecule in the subset of patients who were enrolled in the "rituximab-refractory" trials.

Similar to what has been observed with cytotoxic chemotherapy and/or rituximab, the activity of the radiolabelled anti-CD20 antibodies is not as high in patients who have bulkier disease and/or larger tumour burdens, 
although the extent of previous therapy may be an even more important variable. Among 54 patients treated with Zevalin, the response rate was $100 \%$ among 14 patients whose largest tumour was less than $5 \mathrm{~cm}$ in diameter, and $65 \%$ among 40 patients whose largest tumour was greater than $5 \mathrm{~cm}$ in diameter [46]. Similarly, among 117 patients treated with Bexxar, the response rate was $71 \%$ (41\% complete response rate) among 63 patients whose largest tumour was less than $5 \mathrm{~cm}$ in diameter, and $65 \%(21 \%$ complete response rate) among 54 patients whose largest tumour was greater than $5 \mathrm{~cm}$ in diameter [47].

Response rates tend to be higher and more durable if patients have received little or no prior therapy for lymphoma. In 76 patients with previously untreated follicular lymphoma, the response rate to I-131 tositumomab was $95 \%$ with $75 \%$ complete response rate and $60 \%$ with documented molecular complete remissions [48]. At a median follow-up of greater than five years, the 5-year progression-free survival rate was $59 \%$, and the median progression-free survival was projected to be 6.1 years. Seventy percent of the 57 complete responders were still in remission four to eight years following therapy. Patients in this trial had a median age of only 49 years, which is more than a decade younger than the universal population of follicular lymphoma patients, and because of unintentional selection bias related to patients travelling to a single institution for treatment, these patients actually had a lower tumour burden and more slowly growing tumour than the typical population of follicular lymphoma patients. Nevertheless, the high response rate and durability of response following a treatment that is delivered during a two-week period is very impressive and as good as or better than one would expect from treatment of such patients with chemotherapy administered over five to six months. A report describing a limited experience with Zevalin appears to confirm the high level of activity in patients with untreated disease based on a $100 \%$ response rate among eight patients with five attaining a complete response [49].

In an analysis of 236 lymphoma patients who received Y-90 ibritumomab tiuxetan, the overall response rate and complete response rates were higher among 63 patients who had received only one chemotherapy regimen prior to the radioimmunotherapy compared to 173 patients who had received two or more regimens. The response rates for the respective populations were $86 \%$ vs. $72 \% \quad(P=0.051)$ and complete response rates were $49 \%$ vs. $28 \%(P=0.004)$ [50]. Table 6 shows that response rates, complete response rates, durability of responses and progression-free survival following treatment with I-131 tositumomab are also higher in patients who have had less prior therapy [51]. The 1177 patients in this analysis also included some patients who received I-131 tositumomab shortly following completion of six to eight months of standard chemotherapy as part of a planned sequential treatment for previously untreated patients.

Because of binding to CD20-positive cells in the bone marrow and the non-specific radiation effects of circulating radiolabelled antibodies, there was concern that some patients who subsequently relapsed following anti-CD20 radioimmunotherapy might have insufficient bone marrow reserve to allow safe delivery of additional cytotoxic therapy. Published reports suggest that subsequent cytotoxic treatment is feasible at full doses, and associated with benefit also for patients who previously received anti-CD20 radioimmunotherapy [52-56]. Retreatment with I-131 tositumomab at a dose of 75 cGy TBI in 32 patients who had previously responded but subsequently relapsed was associated with a $56 \%$ response rate, $22 \%$ complete response rate, median duration of response of 11 months, and toxicity that was similar to that seen during an initial therapy [52]. Among 58 patients treated at Mayo Clinic, who had relapsed after Zevalin therapy, subsequent chemotherapy was associated with no more marrow toxicity than seen in contemporary controls who had received similar chemotherapy, but had not received radiolabelled antibodies previously [53]. At the time of the report, eight patients had gone on to receive high-dose chemotherapy with stem cell rescue after successful autologous stem cell harvest. A larger analysis of 153 patients who received treatment following relapse after Zevalin therapy noted response rates of $80 \%$ for focal radiation therapy, 53\% for chemotherapy and $58 \%$ for rituximab $[54,55]$. Among 38 patients treated at Cornell who had relapsed after Bexxar therapy, subsequent chemotherapy was also safely given, and several patients attained a tumour response, including nine who underwent allogeneic or autologous stem cell transplant [56].

Table 6 Correlation between efficacy and timing of I-131 tositumomab anti-CD20 radioimmunotherapy in relation to other treatments for low-grade and transformed CD20 positive B-cell lymphoma

\begin{tabular}{lllll}
\hline & 1st therapy & 2nd therapy & 3rd therapy & 4th therapy \\
\hline Number of patients & 141 & 226 & 228 & 540 \\
Response rate, $\%$ & 95 & 73 & 58 & 46 \\
Median response duration, months & Not reached & 35 & 16 & 12 \\
Complete response rate, $\%$ & 78 & 46 & 32 & 23 \\
PFS $>1$ year, $\%$ & 82 & 59 & 42 & 27 \\
\hline
\end{tabular}

Modified from Gregory et al. [51]; PFS, progression free survival 
Several studies in patients with newly diagnosed follicular lymphoma have demonstrated the feasibility of administering standard doses of anti-CD20 radioimmunotherapy immediately following six to eight cycles of standard chemotherapy. These trials have included CHOP chemotherapy followed by Bexxar $(n=102)$ [57], CVP chemotherapy followed by Bexxar ( $n=30)$ [58], fludarabine followed by Bexxar ( $n=35$ ) [59] and rituximab+CHOP or rituximab+CVP followed by Zevalin $(n=28)$ [60]. In all of these studies, the addition of radioimmunotherapy was not associated with more toxicity than has been seen in other settings; and there was some increase in the response rate. Only one of these trials involved giving radioimmunotherapy following a combination of chemotherapy and rituximab, which is the most popular treatment regimen for low-grade lymphoma [60]. There is an ongoing trial that compares $\mathrm{CHOP}+$ rituximab to $\mathrm{CHOP}$ followed by I-131 tositumomab.

Another issue is whether anti-CD20 radioimmunotherapy can be safely administered to patients who relapse after previous high-dose chemotherapy and autologous stem cell rescue. Such patients were ineligible for the key registration trials for these products. A limited experience in eight patients who subsequently received Y-90 ibritumomab tiuxetan following relapse after an autologous transplant suggested that it is feasible to treat such patients with standard dose anti-CD20 radioimmunotherapy [61]. On the other hand, in a phase I dose escalation trial in 15 patients who had previously undergone high-dose chemotherapy with stem cell rescue, it appeared that 2 $\mathrm{mCi} / \mathrm{kg}$ was the maximum tolerated dose for the product in the post-autologous transplant setting [62].

Radioimmunotherapy has been safely integrated into the treatment of stem cell transplant patients as a replacement for TBI, and has been explored in higher doses as a single agent. Based on estimates of dosing to critical target organs, early trials of high-dose anti-CD20 radioimmunotherapy utilised 280-785 mCi of I-131-labelled anti-CD20 antibody B1 [63-65]. There was a 79\% complete response rate among the first 29 relapsed lymphoma patients so treated, and a $42 \%$ progression-free survival rate at a median follow-up of 42 months [65]. Analysis has suggested a maximum tolerated dose of 25 Gy to the key target organs for I-131 tositumomab when it is combined with etoposide $(60 \mathrm{mg} / \mathrm{kg}$ ) and cyclophosphamide $(100 \mathrm{mg} / \mathrm{kg})(\mathrm{EC})$ high-dose chemotherapy in patients with relapsed lymphoma [66]. At two years of follow-up, compared to a cohort of contemporary control patients, outcomes were better for the patients who received anti-CD20 radioimmunotherapy with their high-dose EC chemotherapy rather than traditional external beam TBI: $68 \%$ vs. $53 \%$ progression-free survival, and $83 \%$ vs. $52 \%$ overall survival [67]. Among follicular lymphoma patients, 27 who received radioimmunotherapy TBI with their chemotherapy had better progression-free survival rates at 5 years, $48 \%$ vs. $29 \%(P=0.006)$, and better overall 5-year sur- vival rates, $67 \%$ vs. 53\% ( $P=0.002)$ compared to 98 relapsed follicular lymphoma patients who received the same chemotherapy with or without traditional external beam TBI [68]. The Y-90 anti-CD20 radiolabelled antibody is also being explored as a high-dose therapy, and/or in conjunction with high-dose chemotherapy with stem cell rescue, with a good safety profile and encouraging efficacy [69-71].

Outcomes for lymphoma patients treated with radiolabelled anti-CD20 antibodies probably differ depending on histology. Observations of patients with intermediate-grade lymphoma, who were enrolled in phase I trials, suggested that response rates were about half those seen in patients with low-grade lymphoma [30, 31]. A recent report describing 104 patients with relapsed large B-cell lymphoma, who were not considered to be candidates for a stem cell transplant approach, seemed to confirm this with an objective response rate of $44 \%$ after treatment with Zevalin [72]. However, the response rate was actually greater than $50 \%$ among 76 patients who had received only chemotherapy, compared to a response rate of only $19 \%$ among patients who previously had been treated with chemotherapy plus rituximab. Responses have also been observed in mantle cell lymphoma with $10 / 12$ patients responding to radiolabelled anti-CD20 as initial treatment [73] and 5/15 in patients who had relapsed or were refractory to prior therapy [74].

Patient selection for anti-CD20 radioimmunotherapy is important to minimise patient risk [20]. Patients should have adequate cell counts and marrow reserve, with limited replacement of bone marrow with malignant CD20-positive cells. Except for recent trials exploring lower radiation doses from radiolabelled anti-CD20 antibodies, all studies have been restricted to patients with less than $25 \%$ of the marrow involved with lymphoma. As summarised in Fig. 2, the rates of grade IV cytopenia associated with Zevalin therapy became progressively worse as marrow involvement increased from $0 \%-5 \%$ to $6 \%-20 \%$, to $20 \%-25 \%$ [75].

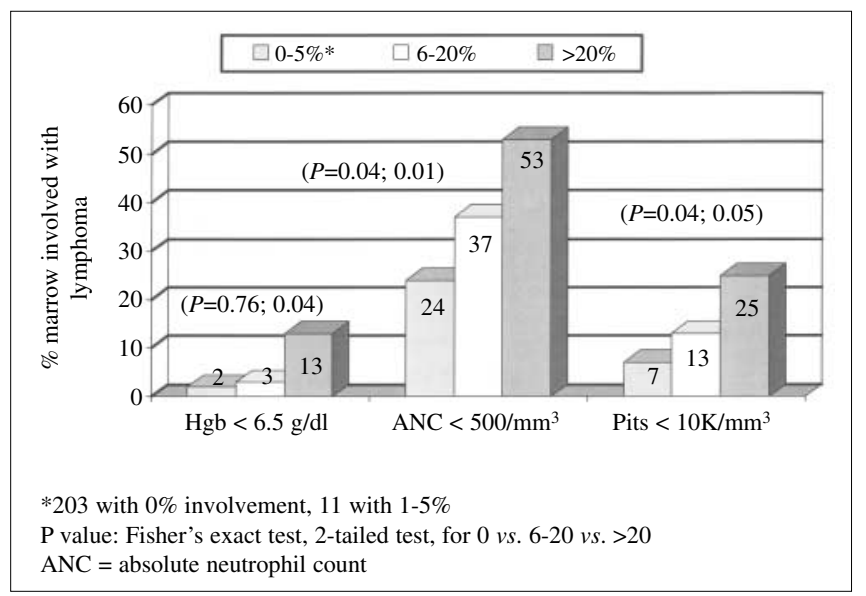

Fig. 2 Relationship between extent of bone marrow involvement with lymphoma and grade III and IV haematotoxicity associated with Y-90 ibritumomab tiuxetan treatment of low-grade and transformed CD20-positive B-cell lymphoma. Modified from Witzig et al. [75] 
Because of the marrow toxicity, there is also interest regarding the activity of lower doses of radiolabelled anti-CD20 antibodies. In patients who were thrombocytopenic with platelet counts between 100000 and 149 000/ml, a $3 \mathrm{mCi} / \mathrm{kg}$ dose of Y-90 ibritumomab tiuxetan resulted in an $83 \%$ response rate in patients with relapsed follicular lymphoma [76], which is the same response rate that was seen at 4 $\mathrm{mCi} / \mathrm{kg}$ [35]. The durability of response at this lower dose was also comparable to that seen in trials at the maximum tolerated dose [77].

The toxicities associated with radiolabelled anti-CD20 may be characterised as: (1) acute, the infusion-related reaction associated with the binding of antibody to circulating CD20-positive cells and the removal of those cells; (2) subacute, the pancytopenia associated with the binding of antiCD20 antibodies to cells in the bone marrow with the damage to nearby progenitor cells and the effects of non-specific radiation as the radiolabelled antibodies pass through the bone marrow vasculature; and (3) chronic, the risk of myelodysplastic syndrome (MDS) and/or acute myelogenous leukaemia (AML) because of sublethal radiation damage to bone marrow stem cells. The infusion reaction problem is self-limited and is now familiar to medical oncologists and haematologists who are used to seeing such reactions in association with rituximab [32]. The bone marrow suppression is typically maximal in the second month after treatment and usually resolves in the third month [75]. It has been hypothesised that the 5-mm path length for the beta emission for Y-90 may be more marrow suppressive than the $1-\mathrm{mm}$ path length for the I-131 beta emission, but the rates of significant cytopenias have been similar in the trials of the two products. In patients who have previously received cytotoxic therapy, and then received radiolabelled antibodies, the rates of MDS/AML are no higher than has been seen in patients with treated lymphoma who have not received radioimmunotherapy, but the median follow-up in these reports has been relatively short [78, 79]. After a median follow-up of more than five years, no episodes of MDS/AML had been observed among the 76 follicular lymphoma patients who received Bexxar as initial therapy [48]. There is also a theoretical concern for long-term risk of other malignancies because of low-dose radiation. A higher rate of stomach cancer has been documented in patients who received thyroid ablative doses of I-131 for hyperthyroidism, which could relate to the physiologic iodine pump in gastric tissues [80]. Hypothyroidism has been documented in about $20 \%$ of patients who have received Bexxar, and is readily managed with thyroid replacement. Human antimouse antibodies (HAMA) have been detected in about $1 \%-2 \%$ of patients receiving ibritumomab with rituximab, as compared to a rate of about $10 \%$ among patients receiving tositumomab. The latter group is exposed to about ten times more mouse protein during the respective therapies. However, the proportion of patients experiencing HAMA was more than $60 \%$ in the trial of Bexxar in previously untreated follicular lymphoma patients [48], presumably because they had not had previous treatment with immunosuppressive cytotoxic therapies.

\section{Conclusions}

Anti-CD20 radiolabelled antibodies are highly effective products for the treatment of B-cell lymphoma. In previously untreated low-grade lymphoma, response rates are as high as for chemotherapy, but are achieved after only two weeks of therapy as opposed to five to six months for cytotoxic chemotherapy using standard dose regimens. Unfortunately, there is little data regarding the benefit of these products in patients who have failed combination therapy with chemotherapy and rituximab, and there is very little data in patients who are truly refractory to rituximab as opposed to being relatively resistant. Patient selection is important to minimise toxicity and optimise efficacy. The modality has been underutilised, probably because of the coordination required between medical oncologists/haematologists and nuclear medicine specialists or radiation oncologists, and the excellent results that have been achieved with chemotherapy plus rituximab in recent years. A randomised trial comparing the anti-CD20 radiolabelled antibodies has been proposed, but it is unclear whether it can ever be completed. An important trial will be a comparison in previously untreated follicular lymphoma patients, of radioimmunotherapy plus rituximab vs. chemotherapy plus rituximab, in terms of efficacy and quality of life.

\section{References}

1. Dillman RO (2001) Monoclonal antibody therapy for lymphoma. Cancer Practice 9:71-80

2. Dillman RO (1997) Magic bullets at last! Finally - approval of a monoclonal antibody for the treatment of cancer!!! Cancer Biother Radiopharm 12:223-225

3. Dillman RO (2003) Treatment of low-grade B-cell lymphoma with the monoclonal antibody rituximab. Semin Oncol 30:434-447

4. McLaughlin P, Grillo-Lopez AJ, Link BK, Levy R, Czuczman MS, Williams ME, Heyman MR, Bence-Bruckler I, White CA, Cabanillas F, Jain V, Ho AD, Lister J, Wey K, Shen D, Dellaire BK (1998) Rituximab chimeric anti-CD20 monoclonal antibody therapy for relapsed indolent lymphoma: half of patients respond to a four-dose treatment program. J Clin Oncol 16:2825-2833

5. Witzig TE, Vukov AM, Habermann TM, Geyer S, Kurtin PJ, Friedenberg WR, White WL, Chalchal HI, Flynn PJ, Fitch TR, Welker DA (2005) Rituximab therapy for patients with newly diagnosed, advanced-stage, follicular grade I nonHodgkin's lymphoma: a phase II trial in the North Central Cancer Treatment Group. J Clin Oncol 23:1103-1108 
6. Colombat P, Salles G, Brousse N, Eftekhari P, Soubeyran P, Delwail V, Deconinck E, Haioun C, Foussard C, Sebban C, Stamatoullas A, Milpied N, Boue F, Taillan B, Lederlin P, Najman A, Thieblemont C, Montestruc F, Mathieu-Boue A, Benzohra A, Solal-Celigny P (2001) Rituximab (anti-CD20 monoclonal antibody) as single first-line therapy for patients with follicular lymphoma with a low tumor burden: clinical and molecular evaluation. Blood 97:101-106

7. Hainsworth JD, Litchy S, Shaffer DW, Lackey VL, Grimaldi M, Greco FA (2005) Maximizing therapeutic benefit of rituximab: maintenance therapy versus re-treatment at progression in patients with indolent non-Hodgkin's lymphoma - a randomized phase II trial of the Minnie Pearl Cancer Research Network. J Clin Oncol 23:1088-1095

8. Ghielmini M, Schmitz SF, Cogliatti SB, Pichert G, Hummerjohann J, Waltzer U, Fey MF, Betticher DC, Martinelli G, Peccatori F, Hess U, Zucca E, Stupp R, Kovacsovics T, Helg C, Lohri A, Bargetzi M, Vorobiof D, Cerny $T$ (2004) Prolonged treatment with rituximab in patients with follicular lymphoma significantly increases event-free survival and response duration compared with the standard weekly x 4 schedule. Blood 103:4416-4423

9. Czuczman MS, Weaver R, Alkuzweny B, Berlfein J, GrilloLopez AJ (2004) Prolonged clinical and molecular remission in patients with low-grade or follicular non-Hodgkin's lymphoma treated with rituximab plus CHOP chemotherapy: 9year follow-up. J Clin Oncol 22:4711-4716

10. Czuczman MS, Koryzna A, Mohr A, Stewart C, Donohue K, Blumenson L, Bernstein ZP, McCarthy P, Alam A, Hernandez-Ilizaliturri F, Skipper M, Brown K, Chanan-Khan A, Klippenstein D, Loud P, Rock MK, Benyunes M, GrilloLopez A, Bernstein SH (2005) Rituximab in combination with fludarabine chemotherapy in low-grade or follicular lymphoma. J Clin Oncol 23:694-704

11. Vose JM, Link BK, Grossbard ML, Czuczman M, GrilloLopez A, Fisher RI (2005) Long-term update of a phase II study of rituximab in combination with CHOP chemotherapy in patients with previously untreated, aggressive nonHodgkin's lymphoma. Leuk Lymphoma 46:1569-1573

12. Feugier P, Van Hoof A, Sebban C, Solal-Celigny P, Bouabdallah R, Ferme C, Christian B, Lepage E, Tilly H, Morschhauser F, Gaulard P, Salles G, Bosly A, Gisselbrecht C, Reyes F, Coiffier B (2005) Long-term results of the RCHOP study in the treatment of elderly patients with diffuse large B-cell lymphoma: a study by the Groupe d'Etude des Lymphomes de l'Adulte. J Clin Oncol 23:4117-4126

13. Habermann TM, Weller E, Morrison VA, Cassileth PA, Cohn J, Dahhil S, Gascoyne RD, Woda B, Fisher B, Peterson BA, Horning SJ (2004) Rituxima-CHOP versus CHOP with or without maintenance rituximab in patients 60 years of age or older with diffuse large B-cell lymphoma: an update. Blood 104:40a [Abstract 127]

14. Pfreundschuh M, Truemper L, Gill D, Osterborg A, Pettengell R, Trneny M, Imrie K, Walewski J, Zinzani P-L, Loeffler M (2004) First analysis of the completed Mabthera international (MInT) trial in young patients with low-risk diffuse large Bcell lymphoma: addition of rituximab to a CHOP-like regimen significantly improves outcome of all patients with the identification of a very favorable subgroup with IPI $=0$ and no bulky disease. Blood 104:48a [Abstract 157]

15. Marcus R, Imrie $\mathrm{K}$, Belch A, Cunningham D, Flores E, Catalano J, Solal-Celigny P, Offner F, Walewski J, Raposo J,
Jack A, Smith P (2005) CVP chemotherapy plus rituximab compared with CVP as first-line treatment for advanced follicular lymphoma. Blood 105:1417-1423

16. Forstpointner R, Dreyling M, Repp R, Hermann S, Hanel A, Metzner B, Pott C, Hartmann F, Rothmann F, Rohrberg R, Bock HP, Wandt H, Unterhalt M, Hiddemann W (2004) The addition of rituximab to a combination of fludarabine, cyclophosphamide, mitoxantrone (FCM) significantly increases the response rate and prolongs survival as compared with FCM alone in patients with relapsed and refractory follicular and mantle cell lymphomas: results of a prospective randomized study of the German Low-Grade Lymphoma Study Group. Blood 104:3064-3071

17. Sehn LH, Donaldson J, Chanabhai M, Fitzgerald C, Gill K, Klasa R, MacPherson N, O'Reilly S, Spinelli JJ, Sutherland J, Wilson KS, Gascoyne RD, Connors JM (2005) Introduction of combined CHOP plus rituximab therapy dramatically improved outcome of diffuse large B-cell lymphoma in British Columbia. J Clin Oncol 23:5027-5033

18. Fisher RI, Leblanc M, Press OW, Maloney DG, Unger JM, Miller TP (2005) New treatment options have changed the survival of patients with follicular lymphoma. J Clin Oncol 23:8447-8452

19. Dillman RO, Chico SD (2005) Improved survival of lymphoma patients after introduction of rituximab. Blood 106:242b [Abstract 4650]

20. Dillman RO (2002) Radiolabeled anti-CD20 monoclonal antibodies for the treatment of B-cell lymphoma. J Clin Oncol 20:3545-3557

21. Cheson BD (2003) Radioimmunotherapy of non-Hodgkin's lymphoma. Blood 101:391-398

22. Siegel JA (1998) Revised Nuclear Regulatory Commission regulations for release of patients administered radioactive materials: outpatient iodine-131 anti-B1 therapy. J Nucl Med 39[Suppl 8]:28s-33s

23. Gates VL, Carey JE, Siegel JA, Kaminski MS, Wahl RL (1998) Nonmyeloablative iodine-131 anti-B1 radioimmunotherapy as outpatient therapy. J Nucl Med 39:1230-1236

24. Rutar FJ, Augustine SC, Kaminski MS, Wahl RL, Siegel JA, Colcher D (2001) Feasibility and safety of outpatient Bexxar therapy (tositumomab and iodine I 131 tositumomab) for nonHodgkin's lymphoma based on radiation doses to family members. Clin Lymphoma 2:164-172

25. Wagner HN Jr, Wiseman GA, Marcus CS, Nabi HA, Nagle CE, Fink-Bennett DM, Lamonica DM, Conti PS (2002) Administration guidelines for radioimmunotherapy of nonHodgkin's lymphoma with (90)Y-labeled anti-CD20 monoclonal antibody. J Nucl Med 43:267-272

26. Wiseman GA, White CA, Stabin M, Dunn WL, Erwin W, Dahlbom M, Raubitschek A, Karvelis K, Schultheiss T, Witzig TE, Belanger R, Spies S, Silverman DH, Berlfein JR, Ding E, Grillo-Lopez AJ (2000) Phase I/II 90-Zevalin (yttrium-90 ibritumomab tiuxetan, IDEC-Y2B8) radioimmunotherapy dosimetry results in relapsed or refractory nonHodgkin's lymphoma. Eur J Nucl Med 27:766-777

27. Erwin WD, Spies SM, Kelly ME, Rao P, Eckersberg-Rhodes TE, Nannapaneni M, Groch MW (2001) Correlation of marrow dose estimates based on serial pretreatment radiopharmaceutical imaging and blood data with actual marrow toxicity in anti-CD20 yttrium-90 monoclonal antibody radioimmunotherapy of non-Hodgkin's B-cell lymphoma. Nucl Med Commun 22:247-255 
28. Wiseman GA, Kornmehl E, Leigh B, Erwin WD, Podoloff DA, Spies S, Sparks RB, Stabin MG, Witzig T, White CA (2003) Radiation dosimetry results and safety correlations from 90Y-ibritumomab tiuxetan radioimmunotherapy for relapsed or refractory non-Hodgkin's lymphoma: combined data from 4 clinical trials. J Nucl Med 44:465-474

29. Wiseman G, Conti P, Vo K, Schilder RJ, Foster P, Gordon LI, Emmanouilides C, Silverman D, Witzig TE (2004) Evaluation of baseline body-weight dosing of yttrium 90 ibritumomab tiuxetan (Zevalin) in patients with relapsed or refractory B-cell nonHodgkin's lymphoma. Blood 104:721a [Abstract 2634]

30. Kaminski MS, Zasadny KR, Francis IR, Fenner MC, Ross CW, Milik AW, Estes J, Tuck M, Regan D, Fisher S, Glenn SD, Wahl RL (1996) Iodine-131-anti-B1 radioimmunotherapy for B-cell lymphoma. J Clin Oncol 14:1974-1981

31. Witzig TE, White CA, Wiseman GA, Gordon LI, Emmanouilides C, Raubitschek A, Janakiraman N, Gutheil J, Schilder RJ, Spies S, Silverman DH, Parker E, Grillo-Lopez AJ (1999) Phase I/II trial of IDEC-Y2B8 radioimmunotherapy for treatment of relapsed or refractory CD20+ B-cell nonHodgkin's lymphoma. J Clin Oncol 17:3793-3803

32. Dillman RO (1999) Infusion reactions associated with the infusion of monoclonal antibodies in the treatment of malignancy. Cancer Metastasis Rev 18:465-471

33. Vose JM, Zelenetz AD, Rohatiner A, Knox S, Stagg R, Kroll S, Tidmarsh G, Kaminski MS (1999) Iodine I 131 tositumomab for patients with follicular non-Hodgkin's lymphoma: overall clinical trial experience by histology. Blood 94:89a [Abstract 387]

34. Davies AJ, Rohatiner AZ, Howell S, Britton KE, Owens SE, Micallef IN, Deakin DP, Carrington BM, Lawrance JA, Vinnicombe S, Mather SJ, Clayton J, Foley R, Jan H, Kroll S, Harris M, Amess J, Norton AJ, Lister TA, Radford JA (2004) Tositumomab and iodine I 131 tositumomab for recurrent indolent and transformed B-cell non-Hodgkin's lymphoma. J Clin Oncol 22:1469-1479

35. Witzig TE, Gordon LI, Cabanillas F, Czuczman MS, Emmanouilides C, Joyce R, Pohlman BL, Bartlett NL, Wiseman GA, Padre N, Grillo-Lopez AJ, Multani P, White CA (2002) Randomized controlled trial of yttrium-90-labeled ibritumomab tiuxetan radioimmunotherapy versus rituximab immunotherapy for patients with relapsed or refractory lowgrade, follicular, or transformed B-cell non-Hodgkin's lymphoma. J Clin Oncol 20:2453-2463

36. Kaminski MS, Zelenetz AD, Press OW, Saleh M, Leonard J, Fehrenbacher L, Lister TA, Stagg RJ, Tidmarsh GF, Kroll S, Wahl RL, Knox SJ, Vose JM (2001) Pivotal study of Iodine I 131 tositumomab for chemotherapy-refractory low-grade or transformed low-grade B-cell lymphomas. J Clin Oncol 19:3918-3928

37. Zelenetz AD, Saleh M, Vose J, Younes A, Kaminski MS (2002) Transformed low grade lymphoma attain durable response following outpatient radioimmunotherapy with tositumoab and iodine I 131 tostitumomab (Bexxar $\left.{ }^{\circledR}\right)$. Blood 100:357a [Abstract 1384]

38. Bartlett NL, Witzig TE, Gordon L, Beck T, Fehrenbacher L, Kornmehl E, Levy R, Terry LN, Murray JL, Raubitschek A, Vo K, White CA (2002) ${ }^{90}$ Y-ibritumomab tiuxetan (Zevalin) radioimmunotherapy for transformed B-cell non-Hodgkin's lymphoma patients. Proc Am Soc Clin Oncol 21:14a [Abstract 51]
39. Leonard JP, Frenette G, Dillman RO, Gregory SA (2001) Interim safety and efficacy results of Bexxar ${ }^{\mathrm{TM}}$ in a large multicenter expanded access study. Blood 98:133a [Abstract 559]

40. Davis TA, Kaminski MS, Leonard JP, Hsu FJ, Wilkinson M, Zelenetz A, Wahl RL, Kroll S, Coleman M, Goris M, Levy R, Knox SJ (2004) The radioisotope contributes significantly to the activity of radioimmunotherapy. Clin Cancer Res 10:7792-7798

41. Witzig TE, Flinn IW, Gordon LI, Emmanouilides C, Czuczman MS, Saleh MN, Cripe L, Wiseman G, Olejnik T, Multani PS, White CA (2002) Treatment with ibritumomab tiuxetan radioimmunotherapy in patients with rituximabrefractory follicular non-Hodgkin's lymphoma. J Clin Oncol 20:3262-3269

42. Horning SJ, Younes A, Jain V, Kroll S, Lucas J, Podoloff D, Goris M (2005) Efficacy and safety of tositumomab and iodine-131 tositumomab (Bexxar) in B-cell lymphoma, progressive after rituximab. J Clin Oncol 23:712-719

43. Gordon LI, Witzig T, Molina A, Czuczman M, Emmanouilides C, Joyce R, Vo K, Theuer C, Pohlman B, Bartlett N, Wiseman G, Darif M, White C (2004) Yttrium 90labeled ibritumomab tiuxetan radioimmunotherapy produces high response rates and durable remissions in patients with previously treated B-cell lymphoma. Clin Lymphoma 5:98-101

44. Wiseman GA, Witzig TE (2005) Yttrium-90 (90Y) ibritumomab tiuxetan (Zevalin) induces long-term durable responses in patients with relapsed or refractory B-Cell non-Hodgkin's lymphoma. Cancer Biother Radiopharm 20:185-188

45. Fisher RI, Kaminski MS, Wahl RL, Knox SJ, Zelenetz AD, Vose JM, Leonard JP, Kroll S, Goldsmith SJ, Coleman M (2005) Tositumomab and iodine-131 tositumomab produces durable complete remissions in a subset of heavily pretreated patients with low-grade and transformed non-Hodgkin's lymphomas. J Clin Oncol 23:7565-7573

46. Flinn IW, Witzig TE, White CA, Gordon L, Emmanoulides C, Cripe LD, Saleh M, Czuczman MS, Spies S, Silverman DH, Burt RW (2001) The Zevalin radioimmunotherapy regimen is active in heavily pretreated, bulky, rituximab refractory NHL. Proc Am Soc Clin Oncol 20:286a [Abstract 1141]

47. Kaminski MS, Leonard JP, Zelenetz AD, Vose JM (2002) Bexxar therapy (tositumomab and iodine I 131 tositumomab) has high response rates in the treatment of bulky low grade, relapsed or refractory non-Hodgkin's lymphoma. Proc Am Soc Clin Oncol 21:5a [Abstract 17]

48. Kaminski MS, Tuck M, Estes J, Kolstad A, Ross CW, Zasadny K, Regan D, Kison P, Fisher S, Kroll S, Wahl RL (2005) 131I-tositumomab therapy as initial treatment for follicular lymphoma. N Engl J Med 352:441-449

49. Sweetenham JW, Dicke K, Acaroli J, Kogel K, Rana TM, Rice LL (2004) Efficacy and safety of yttrium 90 ibritumomab tiuxetan (Zevalin) therapy with rituximab maintenance in patients with untreated low-grade follicular lymphoma. Blood 104:720a [Abstract 2633]

50. Emmanouilides CE, Witzig TE, Molina A, Gordon LI Multani P, Wiseman GA, Darif M, Murray JL, Lister J, White CA (2003) Improved safety and efficacy of yttrium-90 ibrituomab tiuxetan radioimmunotherapy when administered as $2^{\text {nd }}$ or $3^{\text {rd }}$ line therapy for relapsed low-grade, follicular, and transformed B-cell non-Hodgkin's lymphoma. Proc Am Soc Clin Oncol 22:595 [Abstract 2392] 
51. Gregory SA, Leonard JP, Vose JM, Zelenetz AD, Horning SJ, Knox SJ, Lister TA, Radford JA, Press OW, Kaminski MS (2005) Superior outcomes associated with earlier use: experience with tositumomab and iodine I 131 tositumomab in 1,177 patients with low-grade, follicular, and transformed non-Hodgkin's lymphoma. Proc Am Soc Clin Oncol 23:585s [Abstract 6561]

52. Kaminski MS, Radford JA, Gregory SA, Leonard JP, Knox SJ, Kroll S, Wahl RL (2005) Re-treatment with I-131 tositumomab in patients with non-Hodgkin's lymphoma who had previously responded to I-131 tositumomab. J Clin Oncol 23:7985-7993

53. Ansell SM, Ristow KM, Habermann TM, Wiseman GA, Witzig TE (2002) Subsequent chemotherapy regimens are well tolerated after radioimmunotherapy with yttrium-90 ibritumomab tiuxetan for non-Hodgkin's lymphoma. J Clin Oncol 20:3885-3890

54. Schilder RJ, Witzig T, Gordon L, Emmanouilides CE, Bartlett NL, Flinn IW, Ugoretz R, Ding E, Czuczman MS, White CA (2002) ${ }^{90} \mathrm{Y}$ ibritumomab tiuxetan (Zevalin) radioimmunotherapy does not preclude effective delivery of subsequent therapy for lymphoma. Proc Am Soc Clin Oncol 21:267a [Abstract 1064]

55. Saleh F, Saleh M, Witzig T, Gordo L, Emmanouilides CE, Raubitschek A, Wiseman G, Vo K, Landin R, White CA (2002) Rituximab administration subsequent to ibritumomab tiuxetan (Zevalin) radioimmunotherapy. Proc Am Soc Clin Oncol 21:8a [Abstract 30]

56. Dosik A, Hack S, Navarro M, Kostakoglu L, Coleman M, Fiore JM, Scarano D, Kroll S, Vallabhajosula S, Goldsmith SJ, Leonard JP (2002) Cytotoxic chemotherapy for nonHodgkin's lymphoma can be safely administered following relapse from iodine 131 tositumomab (Bexxar). Proc Am Soc Clin Oncol 21:267a [Abstract 1065]

57. Press OW, Unger JM, Braziel RM, Maloney DG, Miller TP, LeBlanc M, Gaynor ER, Rivkin SE, Fisher RI (2003) A phase 2 trial of CHOP chemotherapy followed by tositumomab/iodine I 131 tositumomab for previously untreated follicular nonHodgkin's lymphoma: Southwest Oncology Group Protocol S9911. Blood 102:1606-1612

58. Link B, Kaminski MS, Coleman M, Leonard JP (2004) Phase II study of CVP followed by tositumomab and iodine I 131 tositumomab (Bexxar therapeutic regimen) in patients with untreated follicular non-Hodgkin's lymphoma. Proc Am Soc Clin Oncol 23:560a [Abstract 6520]

59. Leonard JP, Coleman M, Kostakoglu L, Chadburn A, Cesarman E, Furman RR, Schuster MW, Niesvizky R, Muss D, Fiore J, Kroll S, Tidmarsh G, Vallabhajosula S, Goldsmith SJ (2005) Abbreviated chemotherapy with fludarabine followed by tositumomab and iodine I 131 tositumomab for untreated follicular lymphoma. J Clin Oncol 23:5696-5704

60. Shipley DL, Spigel DR, Carrell DL, Dannaher C, Greco FA, Hainsworth JD (2004) Phase II trial of rituximab and short duration chemotherapy followed by ${ }^{90} \mathrm{Y}$-ibritumomab tiuxetan as first-line treatment for patients with follicular lymphoma: a Minnie Pearl Cancer Research Network phase II trial. Proc Am Soc Clin Oncol 23:560a [Abstract 6519]

61. Jacobs SA, Vidnovic N, Joyce J, McCook B, Torok F, Avril N (2005) Full-dose 90Y ibritumomab tiuxetan therapy is safe in patients with prior myeloablative chemotherapy. Clin Cancer Res 11:7146s-7150s

62. Vose JM, Bierman PJ, Lynch JC, Bociek GR, Multani PS, Armitage JO (2003) Phase I clinical trial of Zevalin (Y-90 ibritu- momab) in patients with B-cell non-Hodgkin's lymphoma with relapsed disease following high-dose chemotherapy and autologous stem cell transplantation. Blood 102:30a [Abstract 92]

63. Press OW, Eary JF, Appelbaum FR, Martin PJ, Badger CC, Nelp WB, Glenn S, Butchko G, Fisher D, Porter B (1993) Radiolabeled-antibody therapy of B-cell lymphoma with autologous bone marrow support. N Engl J Med 329:1219-1224

64. Press OW, Eary JF, Appelbaum FR, Martin PJ, Nelp WB, Glenn S, Fisher DR, Porter B, Matthews DC, Gooley T (1995) Phase II trial of 131I-B1 (anti-CD20) antibody therapy with autologous stem cell transplantation for relapsed B cell lymphomas. Lancet 346: 336-340

65. Liu SY, Eary JF, Petersdorf SH, Martin PJ, Maloney DG, Appelbaum FR, Matthews DC, Bush SA, Durack LD, Fisher DR, Gooley TA, Bernstein ID, Press OW (1998) Follow-up of relapsed B-cell lymphoma patients treated with iodine-131labeled anti-CD20 antibody and autologous stem-cell rescue. J Clin Oncol 16:3270-3278

66. Rajendran JG, Fisher DR, Gopal AK, Durack LD, Press OW, Eary JF (2004) High-dose (131)I-tositumomab (anti-CD20) radioimmunotherapy for non-Hodgkin's lymphoma: adjusting radiation absorbed dose to actual organ volumes. J Nucl Med 45:1059-1064

67. Press OW, Eary JF, Gooley T, Gopal AK, Liu S, Rajendran JG, Maloney DG, Petersdorf S, Bush SA, Durack LD, Martin PJ, Fisher DR, Wood B, Borrow JW, Porter B, Smith JP, Matthews DC, Appelbaum FR, Bernstein ID (2000) A phase I/II trial of iodine-131-tositumomab (anti-CD20), etoposide, cyclophosphamide, and autologous stem cell transplantation for relapsed B-cell lymphomas. Blood 96:2934-2942

68. Gopal AK, Gooley TA, Maloney DG, Petersdorf SH, Eary JF, Rajendran JG, Bush SA, Durack LD, Golden J, Martin PJ, Matthews DC, Appelbaum FR, Bernstein ID, Press OW (2003) High-dose radioimmunotherapy versus conventional highdose therapy and autologous hematopoietic stem cell transplantation for relapsed follicular non-Hodgkin lymphoma: a multivariable cohort analysis. Blood 102:2351-2357

69. Winter JN (2004) Combining yttrium 90-labeled ibritumomab tiuxetan with high-dose chemotherapy and stem cell support in patients with relapsed non-Hodgkin's lymphoma. Clin Lymphoma 5[Suppl 1]:S22-S26

70. Nademanee A, Forman SJ, Molina A, Kogut N, Fung HC, Yamauchi D, Anderson A-L, Smith D, Liu AN, Raubitschek A (2004) High-dose radioimmunotherapy with yttrium 90 ibritumomab tiuxetan with high-dose etoposide and cyclophosphamide followed by autologous hematopoietic cell transplant for poor-risk or relapsed B-cell non-Hodgkin's lymphoma: update of a phase I/II trial. Proc Am Soc Clin Oncol 23:557 [Abstract 6504]

71. Joyce J, Schuster MW, McCook B, Torok F, Avril N, Vidnovic N, Jacobs SA (2005) Experience with yttrium 90 ibritumomab tiuxetan after autologous stem cell transplant in patients with non-Hodgkin's lymphoma. Proc Am Soc Clin Oncol 23:602s [Abstract 6669]

72. Morschhauser F, Huglo D, Martinelli G, Paganelli G, Zinzani PL, Hadjiyiannakis D, Liberati A, Illidge T, Milpied N, Stein H, Kalmus J, Morel P, Reimann U, Marcus R (2004) Yttrium90 ibritumomab tiuxetan (Zevalin) for patients with relapsed/refractory diffuse large B-cell lymphoma not appropriate for autologous stem cell transplantation: results of an open-label phase II trial. Blood 104:41a [Abstract 130] 
73. Zelenetz AD, Donnelly G, Halaas J, Sgouros G, Humm J, Popplewell L, Reyes S, Maignan K, Campbell C, Moskowitz CH, Nimer SD, Pandit-Taskar N, Divgi C (2003) Initial treatment of mantle cell lymphoma with sequential radioimmunotherapy with tositumomab/Iodine I131 I-tositumomab followed by CHOP chemotherapy results in a high complete remission rate. Blood 102:406a [Abstract 1477]

74. Oki Y, Pro B, Delpassand E, Ballaster V, McLaughlin P, Romaguera J, Wang M, Hagemeister FB, Younes A (2004) A phase II study of Ytrium 90 ibritumomab tiuxetan (Zevalin) for treatment of patients with relapsed and refractory mantle cell lymphoma. Blood 104:720a [Abstract 2632]

75. Witzig TE, White CA, Gordon LI, Wiseman GA, Emmanouilides C, Murray JL, Lister J, Multani PS (2003) Safety of yttrium-90 ibritumomab tiuxetan radioimmunotherapy for relapsed low-grade, follicular, or transformed nonHodgkin's lymphoma. J Clin Oncol 21:1263-1270

76. Wiseman GA, Gordon LI, Multani PS, Witzig TE, Spies S, Bartlett NL, Schilder RJ, Murray JL, Saleh M, Allen RS, Grillo-Lopez AJ, White CA (2002) Ibritumomab tiuxetan radioimmunotherapy for patients with relapsed or refractory non-Hodgkin's lymphoma and mild thrombocytopenia: a phase II multicenter trial. Blood 99:4336-4342
77. Schilder R, Molina A, Bartlett N, Witzig T, Gordon L, Murray J, Spies S, Wang H, Wiseman G, White C (2004) Follow-up results of a phase II study of ibritumomab tiuxetan radioimmunotherapy in patients with relapsed or refractory lowgrade, follicular, or transformed B-cell non-Hodgkin's lymphoma and mild thrombocytopenia. Cancer Biother Radiopharm 19:478-481

78. Czuczman M, Witzig TE, Gaston I, Skikne BS, Dimitrov G, Gordon LI, Emmanouilides C, White CA (2002) Zevalin ${ }^{\mathrm{TM}}$ radioimmunotherapy is not associated with an increased incidence of secondary myelodysplastic syndrome or acute leukemia. Blood 100:357a [Abstract 1386]

79. Bennett JM, Kaminski MS, Leonard JP, Vose JM, Zelenetz AD, Knox SJ, Horning S, Press OW, Radford JA, Kroll SM, Capizzi RL (2005) Assessment of treatment-related myelodysplastic syndromes and acute myeloid leukemia in patients with non-Hodgkin lymphoma treated with tositumomab and iodine I131 tositumomab. Blood 105:4576-4582

80. Holm LE, Hall P, Wiklund K, Lundell G, Berg G, Bjelkengren G, Cederquist E, Ericsson UB, Hallquist A, Larsson LG, Lidberg M, Lindberg S, Tennvall J, Wicklund H, Boice Jr JD (1991) Cancer risk after idoine-131 therapy for hyperthyroidism. J Natl Cancer Inst 83:1072-1077 